\title{
Copper and disease resistance in sheep: a rare natural confirmation of interaction between a specific nutrient and infection
}

\author{
By N. F. SutTle and D. G. Jones, Moredun Research Institute, 408 Gilmerton \\ Road, Edinburgh $\mathrm{EH} \mathrm{7} 7 \mathrm{7FH}$
}

'Cause and effect' relations between nutrition and susceptibility to infection on natural diets have rarely been demonstrated in any species. Such associations might be anticipated since the body responds to infection with considerable changes in protein metabolism (Baracos, 1986), basal metabolic rate (Chandra, 1980) and trace element distribution (Beisel et al. 1973), indicating that the disposition of nutrients plays an important role in mounting resistance to the pathogen. Nevertheless, evidence for the effects of specific nutrients on the course of infection is sparse. The object of the present paper is to review the existing literature critically and then present new evidence that a natural deficiency of copper in lambs is associated with an increased susceptibility to infection.

Non-specific effects of infection on nutrient utilization and of nutritional status on susceptibility to infection have been found in sheep as in other species. For example, Jones et al. (1982) showed that lambs with experimentally induced chronic pneumonia required $25 \%$ more food to reach the same body-weight as uninfected lambs; whether infection had adversely affected the utilization of several nutrients or just one was unknown. In chronic ovine nematode infections severe impairment of skeletal growth and food utilization together with marked reductions in the deposition of fat, protein and minerals in the body, have all been observed (Sykes et al. 1979). Evidence that nutritional status influences susceptibility to infection is contained in a paper by Eales et al. (1986) who found that twin-bearing ewes in poor bodily condition, indicative of undernutrition during pregnancy, are more likely to give birth to lambs which develop enteritis ('watery mouth') than those in good bodily condition. However, as with the associations between protein-energy malnutrition and susceptibility to infection in infants (e.g. Chandra, I980), it is unclear whether deficiencies of protein, energy, micronutritients or intake of colostrum per se were predisposing factors.

\section{Single nutrients and immunity: in vitro evidence}

Evidence for effects of specific nutrients on disease resistance comes largely from studies in small laboratory animals fed on highly purified diets and is often indirect, being based on in vitro tests of immunocompetence. For example, experimental selenium deficiency has been associated with impaired microbicidal activity in rats (Serfass \& Ganther, 1975; Arthur et al. 1985) and cattle (Boyne \& Arthur, 1979) when phagocytes were challenged with Candida albicans in vitro. $\mathrm{Cu}$ deficiency in sheep and cattle similarly inhibited the candidacidal activity of 
peripheral blood leucocytes (Jones \& Suttle, I981); correlated reductions in the intracellular activity of an antioxidant cuproenzyme, superoxide dismutase (EC I.I5.I.I; SOD) gave rise to speculation that the ability to remove toxic by-products of the 'respiratory burst' was compromised.

Other in vitro studies suggest that the effects of trace elements on immune function are multifaceted. Thus, in addition to its effects on phagocyte function, dietary $\mathrm{Cu}$ deficiency has been associated with impaired antibody production by mouse splenocytes (Prohaska \& Lukasewycz, 1981; Vyas \& Chandra, 1983), altered distribution of spleen lymphocyte subpopulations (Lukasewycz et al. 1985), and decreased mitogen reactivity of the same cells (Lukasewycz \& Prohaska, 1983; Lukasewycz et al. 1985) and of sheep peripheral blood lymphocytes (Jones et al. 1986b). Moreover, cell-mediated cytotoxicity (Flynn \& Yen, 198I) and interleukin-I production are suppressed (Flynn et al. 1984), T-lymphocyte proliferation impaired and the expression of specific $\mathrm{T}$-cell surface markers altered (Flynn, 1984) in spleen cells cultured in Cu-free medium. Extensive studies on experimental zinc deficiency have demonstrated a similar variety of depressive effects on the function of lymphocytes from man (Chandra, 1980) and experimental animals (Gross et al. 1979; Fernandes et al. 1979; Chandra \& Au, 1980; Dowd et al. 1986) as well as impaired neutrophil chemotaxis (Weston et al. 1977). As with $\mathrm{Cu}, \mathrm{Zn}$-depleted media alter numerous responses of cultured lymphocytes (Flynn \& Yen, 1981; Flynn, 1984; Flynn et al. 1984).

A major difficulty in interpreting in vitro studies is that the results obtained can be completely dependent on the experimental conditions chosen. For example in $Z n$ deficiency in rats, the mitogenic responses of splenic lymphocytes to concanavalin $A$ (Con $A$ ) were impaired, but those of cells derived from the thymus were unaffected (Gross \& Newberne, 1980). However, responses to a second T-lymphocyte stimulator, phytohaemagglutinin, were diminished in both preparations and differential responses of T-cell subsets were implicated. Kramer et al. (1986) have shown that removal of macrophages changed the pattern of mitogen responses in splenocyte populations from Cu-depleted mice, indicating that cellular interactions during in vitro tests can profoundly influence their outcome. The opportunities for such interactions are clearly multiplied considerably when the response of the whole animal to the challenge of an infection is considered.

Two observations illustrate the dangers of extrapolating from in vitro tests of immune function to disease resistance in vivo. First, strains of mice which show poor T-lymphocyte responses to mitogen stimulation in vitro are no more prone to natural infection than genetically-superior responders (I. Malave, personal communication). Second, Esa \& Reissig (1985) showed that the acquisition of immunity, as measured by survival, to mouse hepatoma virus was delayed in protein deficiency. Significantly, their parallel in vitro investigations showed that mitogen responses to Con $A$ were enhanced, possibly due to impaired suppressor cell activity; thus in vivo and in vitro studies on the same animals gave rise to opposite assessments of the impact of a nutritional deficiency on the course of an infection. 


\section{Single nutrients and immunity: in vivo evidence}

Evidence that specific nutrient deficiencies impair resistance to infection in vivo is relatively rare and again mostly limited to experiments in laboratory animals. Several decades ago Miles (195I) reported that protein-depleted mice showed poor responses in terms of neutralizing antibody production following challenge with louping-ill virus and, more recently, Bhuyan \& Ramalingaswmi (r973) reported similar effects on tuberculin sensitivity. Gershwin et al. (1985) concluded that bacterial infections are generally aggravated when small laboratory animals are deprived of dietary protein. Turning to micronutrients, $\mathrm{Cu}$ deficiency in rats was associated with decreased resistance to Salmonella typhimurium infection, and depressed reticuloendothelial activity (Newberne et al. 1968). In mice, splenomegaly and thymic degeneration (Prohaska et al. 1983) and enhanced susceptibility to various infections including Pasteurella haemolytica (Jones \& Suttle, 1983) and trypanosomiasis (Omole \& Onawumni, 1979) are all reported consequences of $\mathrm{Cu}$ deficiency. Rare cases of nutritional $\mathrm{Cu}$ deficiency have been reported in human infants on parenteral nutrition and they were characterized by recurrent infections often leading to pulmonary sepsis (Al-Rashid \& Spangler, 1971; Karpel \& Peden, 1972). Zn deficiency similarly impairs disease resistance in rodents (Fernandes et al. 1979; Chandra \& Au, 1980) and is associated with rapid and pronounced atrophy of the thymus (Chandra \& Au, 1980).

The outcome of in vivo studies can also be affected by the experimental conditions chosen. Thus, the humoral responses of vitamin E- or Se-deficient chicks to sheep erythrocytes were depressed at low but not high doses of antigen and in 2week-old, but not in 3-week-old animals (Marsh et al. 1981). The severity of deficiency may also influence the outcome of a nutrient $x$ infection interaction: morbidity and mortality following challenge with bacterial pathogens are markedly increased in severely iron-deficient rats but reduced by a moderate dietary deficiency (Brock \& Mainou-Fowler, 1986). Interestingly, susceptibility to infection can also be enhanced by excesses of minerals such as $\mathrm{Fe}$ (Murray et al. 1975; Kochan et al. 1978), Cu (Vaughn \& Weinburg, 1978; Hill, 1980) and Se (Marsh et al. 1981). However, it should be noted that in all these examples the diets used were highly purified, and the deficiency or excess produced was often severe.

The whole-body response to microbial invasion often includes specific or non-specific inflammatory reactions, or both, and there is evidence that these can also be influenced by nutritional status. Jones (1984) reported that both acute, histamine-induced oedema and delayed hypersensitivity reactions to oxozalone and sheep erythrocytes were enhanced in Cu-depleted mice. Cu deficiency similarly enhanced acute inflammatory reactions in rats (Denko, 1979; Velo et al. 1982; Kishore et al. 1984) although the effects on chronic inflammation are more contentious (Velo et al. 1982; Kishore et al. 1984). Effects of $\mathrm{Cu}$ deficiency on the inflammatory response may be mediated by the two Cu-dependent enzymes, ferroxidase (EC I.16.3.1) and SOD, since both exhibit anti-inflammatory activity when administered exogenously (Denko, 1979; Huber et al. 1977), as do a variety 
of $\mathrm{Cu}$ complexes (Sorensen et al. 1983). It is interesting to note that some injectable $\mathrm{Cu}$ preparations used for the treatment of deficiency in grazing animals can cause local tissue reactions (Suttle, 198I), acute toxicity and anaphylactic shock: this may reflect the impaired ability of some $\mathrm{Cu}$-deficient animals to cope with a cytotoxic agent, be it free $\mathrm{Cu}^{2+}$ ions, chelating agent or the suspending matrix.

\section{Natural nutrient deficiences and infection}

Examples of enhanced susceptibility to infection on natural diets are largely confined to young infants or animals with rare genetic defects in trace-element metabolism. Infants with Menkes' disease, an inherited defect in Cu absorption, have a history of recurrent infections particularly of the respiratory tract (Danks et al. 1972) which has been associated with a variety of impaired immune responses (Pedroni et al. 1975; Sullivan \& Ochs, 1978). Similarly, children with an inherited defect of $\mathrm{Zn}$ absorption (acrodermatitis enterohepathica) often suffer from recurrent diarrhoea and infections (Hambidge et al. 1978). The inherited defect in $\mathrm{Zn}$ deficiency in man has its equivalent in the $\mathrm{A}_{4} 6$ trait in Friesian cattle: affected animals show thymic atrophy, depressed cell-mediated immunity and diarrhoea (which all respond to $\mathrm{Zn}$ therapy) on natural diets that provide adequate $\mathrm{Zn}$ for normal animals (Brummerstedt et al. 1974, 1977). However, recent studies showing reductions in mortality in Indonesian children given supplementary

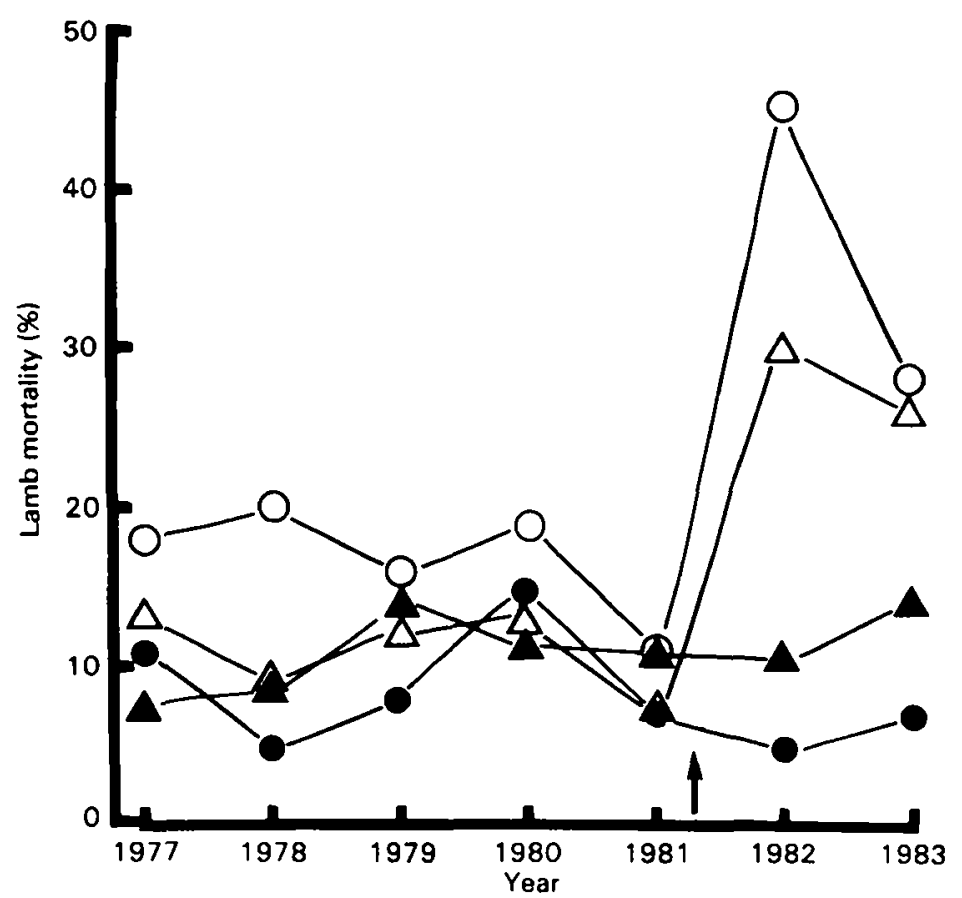

Fig. 1. The effect of pasture improvement $(\uparrow)$ on annual mortality (\%) up to 24 weeks in lambs of four different genotypes: Scottish Blackface $(O)$, Welsh Mountain $(O)$, low line $(\Delta)$ and high line $(\Delta)$. Lines were produced by selecting for low or high plasma copper within a Scottish Blackface $x$ Welsh Mountain inbred cross (from Woolliams et al. 1986). 
vitamin $A$, are believed to involve improved resistance to diarrhoea and respiratory disease (Sommer, 1986) without a component of inherited susceptibility to vitamin A deficiency. Also of relevance is the observation that $\mathrm{Cu}$ supplementation markedly reduces the incidence of infections in infants recovering from marasmus (Castillo-Duran et al. 1983).

\section{$C u$ deficiency and infection in lambs}

It is against this background of limited information on specific natural nutrient deficiencies influencing disease resistance that we present a summary of an experiment which shows a clear connection between $\mathrm{Cu}$ deficiency and disease resistance in a large flock of 400 lambs, albeit with an important genetic component (Woolliams et al. 1986). Early investigations had shown that two breeds of sheep reared under identical conditions on hill pasture differed in their susceptibility to $\mathrm{Cu}$ deficiency: the Scottish Blackface ewe often had lower plasma $\mathrm{Cu}$ concentrations than the Welsh Mountain ewe and, in years of high swayback incidence (swayback is an enzootic ataxia which is prevented by $\mathrm{Cu}$ supplementation), Welsh Mountain lambs were rarely affected whereas many Scottish Blackface lambs succumbed (Wiener \& Field, 1969).

When the hill pasture was improved by liming and reseeding, the Cu status of ewes and lambs declined and there was a sudden upsurge in lamb mortality amongst Scottish Blackface but not Welsh Mountain lambs (Fig. 1). That this breed $x$ environment interaction involved a $\mathrm{Cu} \times$ infection relation was shown by the changes induced by genetic manipulation and $\mathrm{Cu}$ supplementation. For four generations ram lambs had been selected for high or low plasma $\mathrm{Cu}$ concentrations from within an inbred Scottish Blackface $\times$ Welsh Mountain cross to produce high

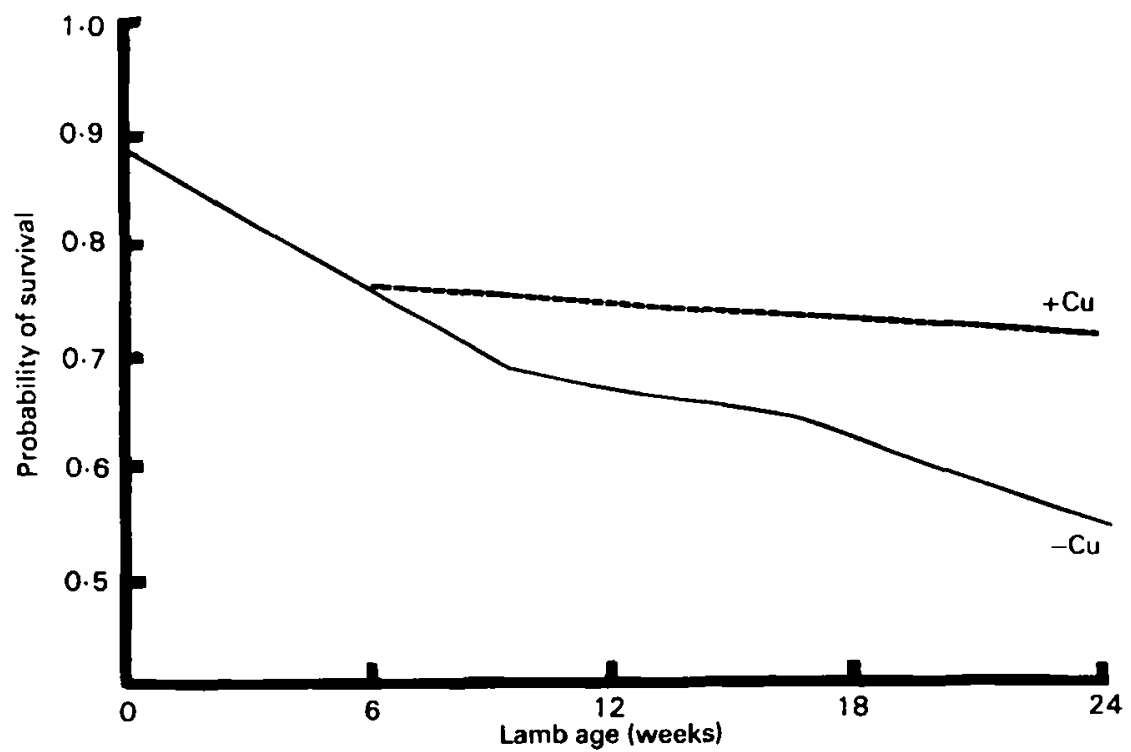

Fig. 2. Treatment of lambs, selected for low plasma copper, with an oral $\mathrm{Cu}$ supplement at 6 weeks of age (---) improved their probability of surviving risks other than swayback when they grazed improved pastures in 1983 (after Woolliams et al. 1986). 


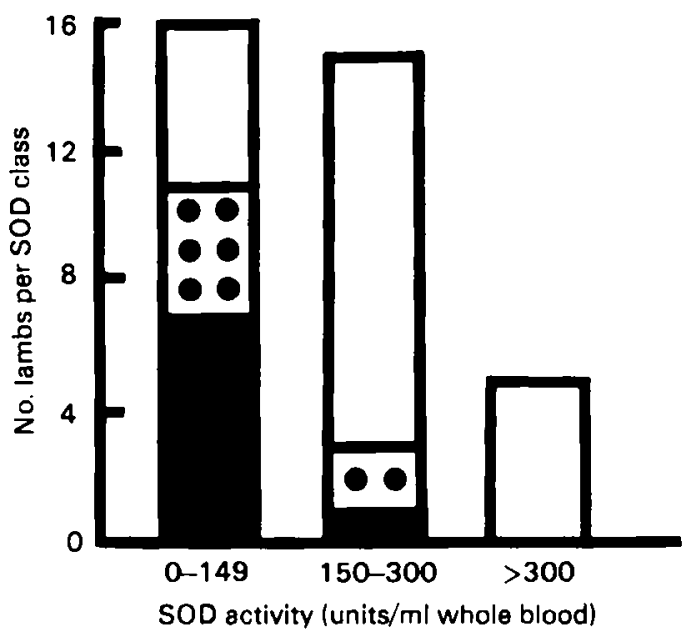

Fig. 3. Deaths due to swayback (O) and other causes $(\square)$ in unsupplemented Scottish Blackface lambs occurred predominantly in those of lowest copper status as measured by the erythrocyte cuproenzyme, superoxide dismutase ( $E C$ 1.1 5.1.1; SOD) at 6 weeks of age. Total height of column gives the number of lambs at risk per SOD class.

and low lines differing only in their plasma $\mathrm{Cu}$ status. The low line, like the Scottish Blackface, showed an upsurge in mortality following pasture improvement not seen in the high line (Fig. I). Swayback was the cause of $40 \%$ of lamb deaths in 1982 but only $2 \%$ in 1983 . Post-mortem findings indicated that most other deaths in both years were associated with bacterial infections, the organisms most commonly isolated being $P$. haemolytica and Escherichia coli. Survival of the lambs could be enhanced by administering $\mathrm{Cu}$ at 6 weeks of age: the effect was clearcut even in the year when swayback was not a problem (Fig. 2), and when it was important both swayback and other causes of death (mostly infections) were reduced. Final evidence for the association between $\mathrm{Cu}$ deficiency and susceptibility to infection was provided by the inverse correlations within a genotype between $\mathrm{Cu}$ status and mortality, the most $\mathrm{Cu}$-deficient individuals being those most likely to succumb to infections or swayback (Fig. 3).

Thus the increased losses of Scottish Blackface and low-line lambs following pasture improvement were largely attributable to an induced $\mathrm{Cu}$ deficiency enhancing susceptibility to swayback and infection, both of which should be regarded as specific consequences of $\mathrm{Cu}$ deficiency. Confirmation for these conclusions can be found in other, less detailed, reports (Whitelaw et al. 1979; Yeoman, 1983 ). The mechanism for reduced disease resistance is unclear but using conventional immune function tests it was found that the responses of peripheral blood lymphocytes to stimulation with mitogens, particularly pokeweed, were markedly depressed in low-line animals and that this immunosuppression was abolished by $\mathrm{Cu}$ supplementation (Jones et al. 1986b). Further studies of acquired immunity in the lambs are in progress. However, the possibility that early lamb 
mortality in particular (Fig. 2) may have reflected an impairment in the transfer of passive immunity from ewe to lamb via the colostrum cannot be ignored.

The association between $\mathrm{Cu}$ deficiency and disease resistance was not confirmed in the incidence of pneumonic lesions (mean $76.0 \%$ ) in lungs of eighty-eight lambs examined at the abattoir: indeed there was some indication that Cu-supplemented lambs were more prone than unsupplemented lambs (D. G. Jones, N. F. Suttle and J. A. Woolliams, unpublished results). The correction of a concurrent Se deficiency, which had been sufficiently severe to retard lamb growth (Suttle et al. 1984), also had no effect on the incidence of chronic pneumonia (Jones et al. 1986a). When the level of parasitic infections in the lambs was assessed in terms of faecal parasite egg counts, there were indications that they were decreased in the most Cu-deficient groups (Jones et al. 1986a) and subsequent work has shown that a challenge dose of nematode larvae are depleted of $\mathrm{Cu}$ more rapidly than their ovine hosts when a Cu-deficient diet is given (M. Clarke and N. F. Suttle, unpublished results). These findings indicate that the impact of a single nutrient deficiency on the incidence and outcome of an infection will depend on the nature of the infection.

\section{Conclusions}

Proven associations between specific nutrient deficiencies and increased susceptibility to infection have rarely been found under natural dietary conditions. The relation between $\mathrm{Cu}$ deficiency and increased mortality in lambs on improved hill pastures described here, to which infections substantially contributed and from which $\mathrm{Cu}$ supplementation afforded protection, therefore represents an important advance. Improved survival in Indonesian children given vitamin A supplements provides a parallel example of a specific nutrient influencing susceptibility to infection in man. Further examples of nutrition $x$ infection interactions under natural dietary conditions would help to justify the continuing extensive studies of experimental depletion and immune defence mechanisms in vitro.

\section{REFERENCES}

Al-Rashid, R. A. \& Spangler, J. (1971). Nero England Fournal of Medicine 285, 841-849.

Arthur, J. R., Boyne, R., Morrice, P. C. \& Nicol, F. (1985). Proceedings of the Nutrition Society $45,63 \mathrm{~A}$.

Baracos, V. (1986). In Proceedings of XIII International Congress of Nutrition, Brighton [T. G. Taylor, editor]. London: John Libbey (In the Press).

Beisel, W. R., Pekarek, R. S. \& Wannemacher, R. W. (1973). In Proceedings of Second International Symposium on Trace Element Metabolism in Animals, Wisconsin, pp. 21 7-240 [W. G. Hoekstra, J. W. Suttie, H. E. Ganther and W. Mertz, editors]. Baltimore: University Park Press.

Bhuyan, U. N. \& Ramalingaswmi, V. (1973). American fournal of Pathology 72, 489-498.

Boyne, R. \& Arthur, J. R. (1979). Fournal of Comparative Pathology 89, $151-158$.

Brock, J. H. \& Mainou-Fowler, T. (1986). Proceedings of the Nutrition Society 45, 305-315.

Brummerstedt, E., Andresen, E., Basse, A. \& Flagstad, T. (1974). Nordisk Veterinae Medicin 26, 279-293.

Brummerstedt, E., Basse, A., Flagstad, T. \& Andresen, E. (1977). American foumal of Pathology 87. 725-728. 
Castillo-Duran, C., Fisberg, M., Vanlenzuela, A., Egana, J. I. \& Uauay, R. (1983). American Fournal of Clinical Nutrition 37, 898-902.

Chandra, R. K. (1980). Current Topics in Immunology Series no. I Immunology of Nutritional Disorders. London: Edward Arnold.

Chandra, R. K. \& Au, B. (1980). American fournal of Clinical Nutrition 33, 736-738.

Danks, D. M., Campbell, P. E., Stevens, B. J., Mayne, V. \& Cartwright, E. (1972). Pediatrics 50, I 88-201.

Denko, C. W. (1979). Agents and Actions 9, 333-336.

Dowd, P. S., Kelleher, J. \& Guillou, P. J. (1986). British Yournal of Nutrition 55, 59-69.

Eales, F. A., Small, J., Gilmour, J. S., Donachie, W., Fitzsimmons, J. \& Dingwall, W. S. (1986). Veterinary Record (In the Press).

Esa, A. H. \& Reissig, M. (1985). Immunology 55, 539-546.

Fernandes, G., Nair, M., Onoe, K., Tanaka, T., Floyd, R. \& Good, R. A. (1979). Proceedings of the National Academy of Sciences, USA 76, 457-461.

Flynn, A. (1984). Fournal of Nutrition $114,2034-2042$.

Flynn, A., Loftus, M. A. \& Finke, J. H. (1984). Nutrition Research 4, 673-679.

Flynn, A. \& Yen, B. R. (1981). fournal of Nutrition $111,907-913$.

Gershwin, M. E., Beach, R. E. \& Hurley, L. S. (1985). Nutrition and Immunity. London: Academic Press.

Gross, R. L. \& Newberne, P. M. (1980). Physiological Reviews 60, 188-302.

Gross, R. L., Osdin, N., Fong, L. \& Newberne, P. M. (I979). American fournal of Clinical Nutrition 32, 1260-1265.

Hambidge, K. M., Walravens, P. A., Neldner, K. H. \& Daughtery, N. A. (1978). In Proceedings of the Third International Symposium on Trace Element Metabolism in Man and Animals, Munich, pp. 413-4I6 [M. Kirchgessner, editor]. Weihenstephan: Abeitskreisfur Tierarnahrungsforschung.

Hill, C. H. (1980). Fournal of Nutrition 110, 430-436.

Huber, W., Menander-Huber, K. B., Saifer, M. G. P. \& Dang, P. H.-C. (1977). In Perspectives in Inflammation, pp. 527-547 [D. A. Willoughby, J. P. Giraud and G. P. Velo, editors]. Lancaster: MTP Press.

Jones, D. G. (1984). Research in Veterinary Science 37, 205-2 10.

Jones, D. G. \& Suttle, N. F. (1981). Research in Veterinary Science 31, $151-156$.

Jones, D. G. \& Suttle, N. F. (1983). Fournal of Comparative Pathology 93, $143^{-149 .}$

Jones, D. G., Suttle, N. F., Jones, G. E., Woolliams, J. A., Woolliams, C. \& Wiener, G. (1986a). In Proceedings of the 5 th International Symposium on Trace Elements in Man and Animals (TEMA 5), Aberdeen, pp. 46-48 [C. F. Mills, I. Bremner and ]. K. Chesters, editors]. Farnham Royal: Commonwealth Agricultural Bureaux.

Jones, D. G., Suttle, N. F., Woolliams, J. A. \& Woolliams, C. (Ig86b). In Proceedings of XIII International Congress of Nutrition, Brighton [T. G. Taylor, editor]. London: John Libbey (In the Press).

Jones, G. E., Field, A. C., Gilmour, J. S., Rae, A. G., Nettleton, P. F. \& McLauchlan, M. (1982). Veterinary Record $110,168-173$.

Karpel, J. T. \& Peden, V. H. (1972). Fournal of Pediatrics 80, 32-37.

Kishore, V., Latman, N., Roberts, D. W., Barnett, J. B. \& Sorensen, J. R. J. (1984). Agents and Actions 14, 274-282.

Kochan, I., Wasynczuk, J. \& McCabe, M. A. (1978). Infection and Immunity 22, 560-567.

Kramer, T. R., Davis, M. A. \& Briske-Anderson, M. J. (I986). In Proceedings of XIII International Congress of Nutrition, Brighton [T. G. Taylor, editor]. London: John Libbey (In the Press).

Lukasewycz, O. A. \& Prohaska, J. R. (1983). Nutrition Research 3, 335-341.

Lukasewycz, O. A., Prohaska, J. R., Meyer, S. G., Schmidke, J. R., Hatfield, S. M. \& Marder, P. (1985). Infection and Immunity 48, 644-647.

Marsh, J. A., Dietert, R. R. \& Combs, G. F. (1981). Proceedings of the Society for Experimental Biology and Medicine $166,228-236$.

Miles, J. A. R. (I95I). British Yournal of Experimental Pathology 32, 295-306.

Murray, M. J., Murray, A. B., Murray, N. J. \& Murray, M. B. (1975). Lancet i, 653-654.

Newberne, P. M., Hunt, C. E. \& Young, V. R. (1968). British fournal of Experimental Pathology $49,44^{8-457}$. 
Omole, T. A. \& Onawumni, O. A. (1979). Annales de Parasitologie Humaine et Comparee 54, $495-506$.

Pedroni, E., Bianachi, E., Vgazio, A. G. \& Burgio, G. R. (1975). Lancet i, I303-1 304.

Prohaska, J. R., Downing, S. W. \& Lukasewycz, O. A. (1983). fournal of Nutrition I13, ${ }_{15} 83^{-1}-1590$.

Prohaska, J. R. \& Lukasewycz, O. A. (1981). Science 21 3, 559-560.

Serfass, R. E. \& Ganther H. E. (1975). Nature 255, 640-64I.

Sommer, A. (1 986 ). In Proceedings of XIII International Congress of Nutrition, Brighton [T. G. Taylor, editor]. London: John Libbey (In the Press).

Sorensen, J. R. J., Oberley, L. W., Crouch, R. K., Kensler, T. W., Kishore, V., Leuthauser, S. W. C., Oberley, T. D. \& Pezeshk, A. (1983). Biological Trace Element Research 5, 257-273.

Sullivan, J. L. \& Ochs, H. D. (1978). Lancet ii, 686.

Suttle, N. F. (1981). Veterinary Record 109, 307-308.

Suttle, N. F., Jones, D. G., Woolliams, J. A., Woolliams, C. \& Wiener, G. (1984). Proceedings of the Nutrition Society $43,103 \mathrm{~A}$.

Sykes, A. R., Coop, R. L. \& Angus, K. W. (1979). Research in Veterinary Science 26, 372-377.

Vaughn, V. J. \& Weinburg, E. D. (1978). Mycopathologica 64, 39-42.

Velo, G. P., Franco, L., Conforti, A. \& Milanino R. (1982). In Inflammatory Diseases and Copper, pp. 329-345 [J. R. J. Sorensen, editor]. New Jersey: Humana Press.

Vyas, D. \& Chandra, R. K. (1983). Nutrition Research 3, 343-349.

Weston, W. L., Huff, J. C., Humbert, J. R., Hambidge, K. M., Neldner, K. H. \& Walravens, P. A. (1977). Archives of Dermatology I 13, 422-428.

Whitelaw, A., Armstrong, R. H., Evans, C. C. \& Fawcett, A. R. (1979). Veterinary Record 104, 455-460.

Wiener, G. \& Field, A. C. (1969). Fournal of Comparative Pathology 79, 7-14.

Woolliams, C. A., Suttle, N. F., Woolliams J. A., Jones, D. G. \& Wiener, G. (1986). Animal Production 42 (In the Press).

Yeoman, G. H. (1983). Veterinary Record $113,547$. 